\author{
ACTA MYCOLOGICA \\ Vol. 43 (1): 49-55 \\ 2008
}

\title{
Influence of osmotic pressure on the growth of three species of genus Zoophthora
}

\author{
JERZY PIĄTKOWSKI and EWA KLICZKOWSKA \\ Institute of Genetics and Microbiology, University of Wrocław \\ Przybyszewskiego 63/77, PL-51-148 Wrocław, jurekp@microb.uni.wroc.pl
}

Piątkowski J., Kliczkowska E.: Influence of osmotic pressure on the growth of three species of the genus Zoophthora. Acta Mycol. 43 (1): 49-55, 2008.

Strains accomodated in the genus Zoophthora are very sensitive to osmotic value of their habitat. Hipertonical molarity of buffers and $\mathrm{NaCl}$ decreases the growth, but this effect strongly depends on the species tested and on the kind of buffer. In $0.66 \%$ phtalan buffer the growth of $Z$. lanceolata is completely stopped whereas Z. psyllae and Z. aphrophora is inhibited only in $50 \%$ comparing to the control.

Key words: Zoophthora, osmotic pressure, influence of buffers on growth

\section{INTRODUCTION}

It is a well-established fact that many species of insects are infected and finally killed by fungi belonging to a variety of genera (Batko 1964a, b; 1974). One of them is the genus Zoophthora.

Investigations have been carried out into the use of entomopathogenic fungi as an alternative to chemical insecticides. However, entomopathogenic fungi are difficult to cultivate under laboratory conditions, so the researches have directed their attention to the factors that may influence the growth and germination of these species (Freimoser et al. 1999) and thus facilitate their cultivation.

The available information about the physical factors affecting the physiology of the entomopathogenic fungi is rather poor. Research on a variety of physical factors has revealed that each species react differently to such factors. It has been noticed that the activity of entomopathogenic fungi against insects may depend on a season (Bajan, Kmitowa 1997; Krejzowa 1988). Although the seasons of the year themselves cannot be regarded as physical factors, we assume that the main factors that affect the physiological activity of the fungi in particular season are light, temperature and air humidity.

Many investigations into the influence of temperature have been reported so far (Yendol 1968; Hall, Bell 1961). Temperature is of importance to the growth of the 
entomopathogenic fungi and to their ability of infecting insects (Miętkiewski et al. 1994). In some instances the influence of temperature is positive (it stimulates), in others a negative one. At temperatures lower than $8^{\circ} \mathrm{C}$ and higher than $36^{\circ} \mathrm{C}$, the spores of Entomophthora virulenta are completely deactivated (Yendol 1968). Other investigations have revealed that the optimal temperature for the viability of the mycelium of particular fungal strain is also optimal for the viability of their spores (Brobyn et al. 1985). The photoperiodic effect (Feng, Xu 1998) or the effect of ultraviolet light on some fungi has also been reported (Braga et al. 1999).

A significant factor which influences the fungal metabolism is moisture. As for the entomopathogenic fungi, this is also a very important factor of their habitat, responsible for viability, rate of growth and intensity of sporulation. For Entomophthora thaxteriana, and E. aphidis the optimal moisture of spore release ranges from 70 to $90 \%$ at $20^{\circ} \mathrm{C}$. As for the viability of the species, they may survive under these conditions for several days but in drier and colder air even for several weeks or months (Wilding 1973).

Another important physical factor that affects the growth and sporulation of those fungi is light. Exposure to electromagnetic waves in the visible range accounts for the effect of periodity of sporulation. The sporulation of most entomopathogenic fungi is light-dependend, but there are species that sporulate at a faster rate in darkness (Latge et al. 1978).

In our study reported on in this paper we cultivated three relative species of the genus Zoophthora on the solid full medium supplemented with saline, phosphate buffer or phtalane buffer at different concentrations. The available literature contains no references to the importance of the osmotic value of the habitat to the physiological activity of fungi, involving the entomopathogenic strains.

\section{MATERIALS AND METHODS}

The strains used in these tests: Zoophthora aphrophorae (Rostrup) Bałazy, $Z$. lanceolata Keller and Z. psyllae Bałazy, were received from Prof. Stanisław Bałazy, Research Centre for Agricultural and Forest Environment, Polish Academy of Sciences. Z. aphrophora was isolated from Aphrophora sp. The species was previously described by Rostrup as Enthomophthora aphrophorae and a second time by Bałazy as Zoophthora miridis (Bałazy 1993). The name Z. aphrophora has been proposed recently by prof. Bałazy (Bałazy 2003). Z. lanceolata was isolated from Empididae and $Z$. psyllae from Trioza urticae. All the strains were isolated in Bavaria, Germany.

The strains were stored on the solid medium supplemented with a hen egg-yolk at $4^{\circ} \mathrm{C}$. Before testing, small samples of mycelium were translocated onto the solid full medium - YPG, and cultivated at $21^{\circ} \mathrm{C}$ in the dark for 5 days. Subsequently, small (7 mm diameter) discs of mycelium from the outer side of the cultivated fungus were cut out and translocated onto plates with solid full media (YPG) supplemented with buffers and/or $\mathrm{NaCl}$ at concentrations of $0.0066 \mathrm{M}, 0.066 \mathrm{M}$ and $0.66 \mathrm{M}$. Use was made of phosphate and phtalan buffer according to the procedure described by Mejbaum-Katzenellenbogen and Mochnacka (1968). We also used media with $0,0066 \mathrm{M}$ phosphate buffer supplemented with such an amount of $\mathrm{NaCl}$ that the final $\mathrm{NaCl}+$ buffer concentration amounted to $0.066 \mathrm{M}$ and $0.66 \mathrm{M}$. Each variant of the "strain + medium" was prepared in four repetitions, and statistical evaluation of the 
diameter length was performed. Air humidity at the time of culturing approached $55 \%$.

The media were prepared according to the following scheme:

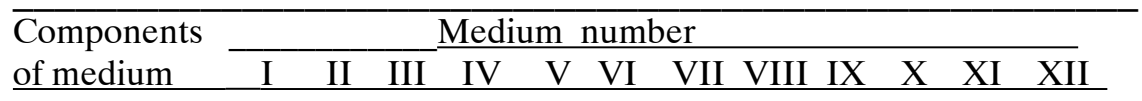

Yeast extract

\begin{tabular}{lcccccccccccc}
{$[\mathrm{g}]$} & 10 & 10 & 10 & 10 & 10 & 10 & 10 & 10 & 10 & 10 & 10 & 10 \\
\hline Peptone $[\mathrm{g}]$ & 10 & 10 & 10 & 10 & 10 & 10 & 10 & 10 & 10 & 10 & 10 & 10 \\
\hline Glucose [g] & 20 & 20 & 20 & 20 & 20 & 20 & 20 & 20 & 20 & 20 & 20 & 20 \\
\hline Agar-agar [g] & 20 & 20 & 20 & 20 & 20 & 20 & 20 & 20 & 20 & 20 & 20 & 20 \\
\hline NaCl [g] & 0.38 & 3.85 & 38.6 & - & - & - & - & - & - & 3.47 & 34.7 & - \\
\hline
\end{tabular}

Phosphate

Buffer $0.66 \mathrm{M}$

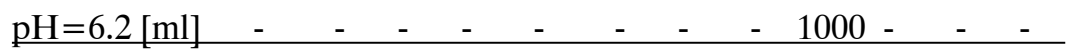

Phosphate

Buffer $0.066 \mathrm{M}$

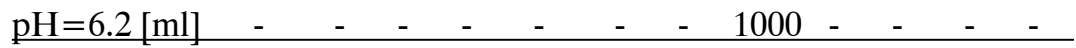

Phosphate

Buffer $0.0066 \mathrm{M}$

$\mathrm{pH}=6.2[\mathrm{ml}] \quad-\quad-\quad-\quad-\quad-\quad-1000-10001000-$

Acidic phthalate

Buffer $0.66 \mathrm{M}$

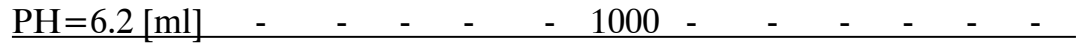

Acidic phthalate

Buffer $0.066 \mathrm{M}$

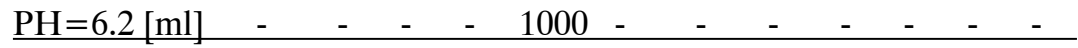

Acidic phthalate

Buffer $0.0066 \mathrm{M}$

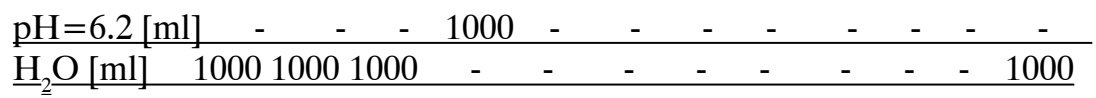

\section{RESULTS AND DISCUSSION}

Figure 1 depicts the effect of osmothic prasure on the growth of the tree strains being tested (including statistically evaluated data).

As we can see, at salt concentrations providing an isoosmotic environment of the medium-variant I $(0.0066 \mathrm{M})$, Zoophthora psyllae grow at the fastest rate; the growth rate for $Z$. aphrophora being slower and that of $Z$. lanceolata the slowest one. In all the testing variants of the medium, the rate of mycelium growth of particular strain is similar in YPG (control, variant XII) and YPG suplemented with $0.066 \mathrm{M}$ buffer (IV, VII), or $0.0066 \mathrm{M} \mathrm{NaCl}(\mathrm{I})$. This implies that low concentrations of $\mathrm{Na}_{2} \mathrm{HPO}_{4}, \mathrm{KH}_{2} \mathrm{PO}_{4} \mathrm{NaCl}$, and phthalate do not affect the rate of growth of the three fungal strains examined.

If the concentration of the phthalate buffer or $\mathrm{NaCl}$ amounts to $0.066 \mathrm{M}(\mathrm{II}, \mathrm{V})$, $Z$. psyllae grows at the same rate as in the control, the diameter of the mycelium being $45.6 \mathrm{~mm}, 51.7 \mathrm{~mm}$ and $46.6 \mathrm{~mm}$, respectively. In the $\mathrm{X}$ variant, when the phosphate 
buffer is also present, but only to support the appropriate $\mathrm{pH}$ (buffer $+\mathrm{NaCl}=$ $0,066 \mathrm{M})$, the growth of $Z$. psyllae is not reduced, compared to the control. In the presence of the $0.066 \mathrm{M}$ phthalate buffer $(\mathrm{V})$ the growth of the fungus seems to be enhanced. A significantly slower growth of the fungus, however, was detected when use was made of the VIII variant with the $0.066 \mathrm{M}$ phosphate buffer. A similar effect was observed upon comparison of the growth of Z. aphrophora and Z. lanceolata on the media with $0.066 \mathrm{M}$ phthalate buffer $(\mathrm{V})$ and $0.066 \mathrm{M}$ phosphate buffer (VIII). The average diameter of the $Z$. aphrophora mycelium on variant $\mathrm{V}$ and variant $\mathrm{V}$ amounted to $28.7 \mathrm{~mm}$ and $22.0 \mathrm{~mm}$, respectively. This finding suggests that additional factor which can inhibit the growth is phosphate ions themselvs. Maybe it is of practical value showing that under some conditions the media made on the basis of the phthalate buffer are more effective than those prepared on the basis of the phosphate buffer.

One of the most interesting and we believe - valuable effects is observed when comparing $Z$. lanceolata and $Z$. aphrophora and $Z$. psyllae on the phtalan buffer at $0,66 \mathrm{M}$ concentrations. It is significant distinction in growth inhibition observed. $Z$. lanceolata is much more efficiently inhibited than the both other strains. As it is shown in figure 1 , the growth of $Z$. lanceolata on this medium is completely stopped as in all other mediums also supplemented with $0,66 \mathrm{M}$ osmotic factors, whereas $Z$. aphrophora and $Z$. psyllae are in this condition still growing. Does the phtalan buffer have protective action against disadvantageous influence of hipertonic value of medium on fungus growth?

The genus of Zoophthora belongs to the order Entomophthorales of the class $\mathrm{Zy}$ gomycetes. The basic characteristics, that distinguish the species of this order from other orders of these class (Mucorales, Zoopagales), are ability of forming separate cells called hyphal bodies and production of conidia that could be actively ejected from the conidiogenous cell. Furthermore, the hyphe of Entomophthorales fungi is, unlike those which exist in Mucorales and Zoopagales, divided by cross walls into segments. In Zoophthora the segments are polycaryotic except for the conidiogenous cell and conidia, which are monocariotic (Bałazy 1993). Characteristic to Zoophthora are also branched conidiophores and sterile hyphae - pseudocystidia.

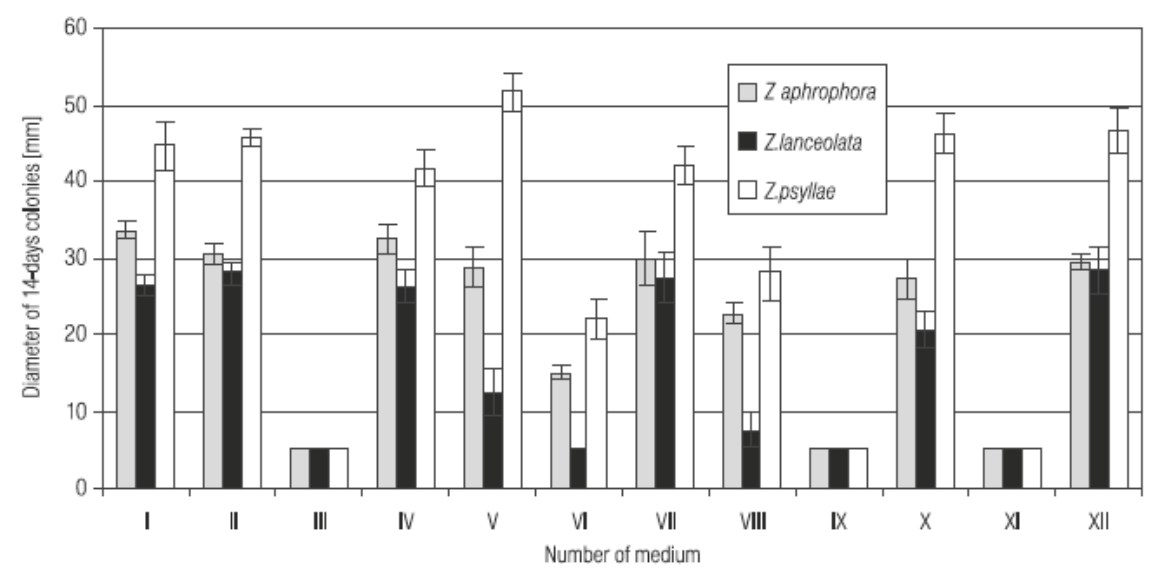

Fig. 1. Effect of buffer concentrations on the growth of three species of the genus Zoophthora. 
Pseudocystidia are thought to be cells which perfore the cuticule of a host, enabling arising of conidiophores on outside of the host body (Brobyn, Wilding 1977).

The morphologies of all these structures are of great importance to the differentiation of the genus Zoophthora into particular species. But if we analyse the polymorphism and the extent to which the structures differ from one another, the difference will appear to be very smal in some instances. For example, on comparing the capillisporal structures as diagnostic features, one may conclude that the differences between the capillispore shapes are very subtile (Keller 1980; Ben-Ze'ev, Kenneth 1981b).

When analysing the importance of morphological features to the diagnostics of fungal species, the question arises whether morphological differences are sufficient to distinguish particular species. In our opinion the analysis of morphological characteristics should be supported by the analysis of physiological properties to a greater extent than it is now.

The aim of our study was not to revise the systematic classification of the species Z . aphrophora, Z. lanceolata or Z. psyllae. More species representing each of the genera should be tested so that conclusions can be drawn about the taxonomic value of osmotic pressure. Correct comparisons of the species require analysis at the molecular level - on the nucleotyde sequence in DNA. But, in our opinion, such properties of the strains as sensitivity to osmotic preassure or to other physiological factors, may be also useful in differentiating those species into particular systematical units.

The osmotic value of the fungal hyphe environment seems to be important, probably because of the exceptional sensitivity of the fungi to the decrease in water concentration inside the cells. The concentration of osmotically active substances in the fungal hyphe habitat, higher than the physiological ones accounts for the efflux of water from the inside of the cells. We woud like to emphasize that because of the high sensitivity of the fungi to osmotic value of the media used for their culturing is of great importance to the growth process, as well as to a variety of physiological processes, such as sporulation and release of secondary metabolites. But, as we can infer from the bars in figure 1, the responses to the varying buffer concentrations differ remarkably from one strain to another.

The difference in sensitivity to the osmotic value of the environment between the fungal strains is also high, when compared the strains from not relative taxonomic units. For the yeast strains we used a storage medium, where one of the components, glycerol, accounted for $50 \%$ of the total content. In such medium the yeast cells can survive at temp. $71^{\circ} \mathrm{C}$ for years, except the Zoophthora species, which survived only one day, when kept in this environment (results not published).

It is not clear why some fungal taxa are so sensitive to water amount. Particular physiological processes involved in this "water-dependence" have not been well recognized so far. Probably, some enzymes in "low water-sensitive" strains change their conformation, especially at an active centre, when water concentration changes. The level of this sensitivity varies from organisms to organisms. Water can be removed completely from yeast and bacteria, but they recover life activity in the water habitat. These differences in viability under low moisture conditions may be of great ecological importance. 
The use of a media differing in osmotic values may be beneficial when detecting and investigating biochemical changes in fungal cell metabolism with the decrease in the water level.

It is worth noticing that the buffers and $\mathrm{NaCl}$ not only decrease the growth of the strains but also the morphology (colour) of particular fungal colony is different, depending to the medium variant, as illustrated in the figure $2 \mathrm{~A}, \mathrm{~B}$.

The medium variants were prepared according to the procedure shown in the schema in materials and methods.

To sum up, the results suggest that osmotic pressure is one of the significant factors that affect growth and presumably other physiological processes of entomopathogenic fungi belonging to the genus Zoophthora. It is obvious that other comparative investigation must be performed, using other species of this kind of fungi.

\section{REFERENCES}

Bałazy S. 1993. Flora Polska. Grzyby (Mycota) 24:Owadomorkowe (Entomophthorales). W. Szafer Institute of Botany, Polish Academy of Sciences, Kraków.

Bałazy S. 2003. On some little known epizootics in noxious and beneficial arthropod populations caused by entomophthoralean fungi. Insect Pathogens and Insect Parasitic Nematodes IOBC Bulletin 26: 63-68.

Batko A 1964a. Remarks on the genus Entomophthora. Bull. Acad. Pol. Ser. Sci. Biol. 12: 319-321.

Batko A. 1964b. On the new genera Zoophthora. Bull. Acad. Pol. Ser. Sci. Biol. 12: 323-326.

Batko A. 1974. Filogeneza a struktury taksonomiczne Entomophthoraceae (Phylogenesis and taxonomic structure of Entomophthoraceae). (In:) C. Nowiński (ed.). Ewolucja biologiczna, szkice teoretyczne i metodologiczne. Polska Akad. Nauk, Ossolineum, Wrocław: 109-303.

Ben-Ze'ev I., Kenneth R. G. 1981. Zoophthora radicans and Zoophthora petchii sp. nov. (Zygomycetes: Entomophthorales) two species of the "sphaerosperma - group" attacking leafhoppersand froghoppers (Hom.). Entomophaga 26: 131-142.

Braga G., Messias C. L., Miller C. D., Flint S. D., Daldwell M., Anderson A. J., Roberts D. W. 1999. Effect of near ultraviolet light (UVA and UVB) on hydrated and germinating conidia of the genus Metarhizium. XXXIII Annual Meeting of the SIP, Irvaine. SIP Program and Abstracts: 28.

Bajan C., Kmitowa K. 1997. Interactions between entomopathogenic and saprophytic fungi. Zar JA. Biostatical Analysis. 32: 47-63.

Brobyn P. J., Wilding N. 1977. Invasive and developmental processes of Entomophthora species infecting aphids. Trans. Brit. Mycol. Soc. 69: 349-366.

Brobyn P. J., Wilding N., Clark S. J. The persistence of infectivity of conigia of the aphid pathogen, Erynia neoaphidis on leaves in the field. Ann. Appl. Biol. 107: 365-376.

Feng M. G., Xu J. H. 1998. Photoperiods affect the growth and sporulation pattern of the liquid and plate cultures of the entomophthoralean fungus Pandora delphacis (Hori) Humber. (In:) VIIth International Colloquium on Invertebrate Pathology, Sapporo. Meetings Program and Abstracts: 55.

Freimoser M., Grundschoher F. Aebi M., Tuor U. 1999. Morphology and growth requirements of the thrips pathogenic fungus Enthomophthora thripidum in in vitro cultures. (In:) XXXIII Annual Meeting of the SIP, Irvaine. SIP Program and Abstracts: 36.

Hall I. M., Bell J. V. 1961. Further studies on the effect of temperature on the growth of some Entomophthoraceus fungi. Journal of Insect Pathology 3: 289-296.

Keller S. 1980. Two new species of the genus Zoophthora Batko (Zygomycetes, Entomophthorales): Z. lanceolata and Z. crassitunicata. Sydowia 33: 167-173.

Latge J.P., Perry D., Papierok B., Coremans-Pelseneer J., Remaudiere G., Resinger O. 1978. Germination d' azygospore d' Entomophthora obscura. Acad. Sci. Paris Ser. 287: 946.

Mejbaum-Katzenellenbogen W., Mochnacka I. 1968. Kurs praktyczny z biochemii. PWN Warszawa.

Wilding N. 1973. The survival of Entomophthora spp. in mummified aphids at different temperatures and humidities. J. Invertebr. Pathol. 21: 309-311.

Yendol W.G. 1968. Factors affecting germination of Entomophthora conidia. J. Invertebr. Pathol. 10: 116-121. 
Wpływ ciśnienia osmotycznego na wzrost trzech gatunków z rodzaju Zoophthora

\section{Streszczenie}

Informacje o wpływie czynników fizycznych na grzyby owadobójcze są w literaturze naukowej raczej skąpe. Donosi się o znaczeniu temperatury, wilgotności powietrza, oraz długości działania światła na wzrost i sporulację wybranych gatunków. W niniejszej pracy przedstawiono wyniki badań nad wpływem różnych stężeń buforu fosforanowego, ftalanowego oraz chlorku sodowego na wzrost szczepów trzech gatunków: Zoophthora lanceolata, Z. psyllae i $Z$. aphrophora. Stężenie buforów i chlorku sodowego, które można uznać za zbliżone do izoosmotycznego w stosunku do komórek grzybów $(0.0066 \mathrm{M})$, nie zmienia szybkości wzrostu szczepów w porównaniu do kontroli. Stężenia dziesięć razy większe spowalniają wzrost, szczególnie w stosunku do Z. lanceolata i przy buforze fosforanowym. Silniej hamuje bufor fosforanowy niż ftalanowy, co może oznaczać, iż jony fosforanowe zwiększają wrażliwość tych grzybów na podwyższone ciśnienie osmotyczne. Stężenie 100 razy większe od izoosmotycznego prawie całkowicie hamuje wzrost, ale w obecności buforu ftalanowego obserwuje się znaczną różnicę we wrażliwości między $Z$. lanceolata a dwoma pozostałymi szczepami, co stwarza nadzieję, iż zachowanie się poszczególnych szczepów gatunków z rodzaju Zoophthora w obecności podwyższonych stężeń buforów może mieć znaczenie diagnostyczne. 

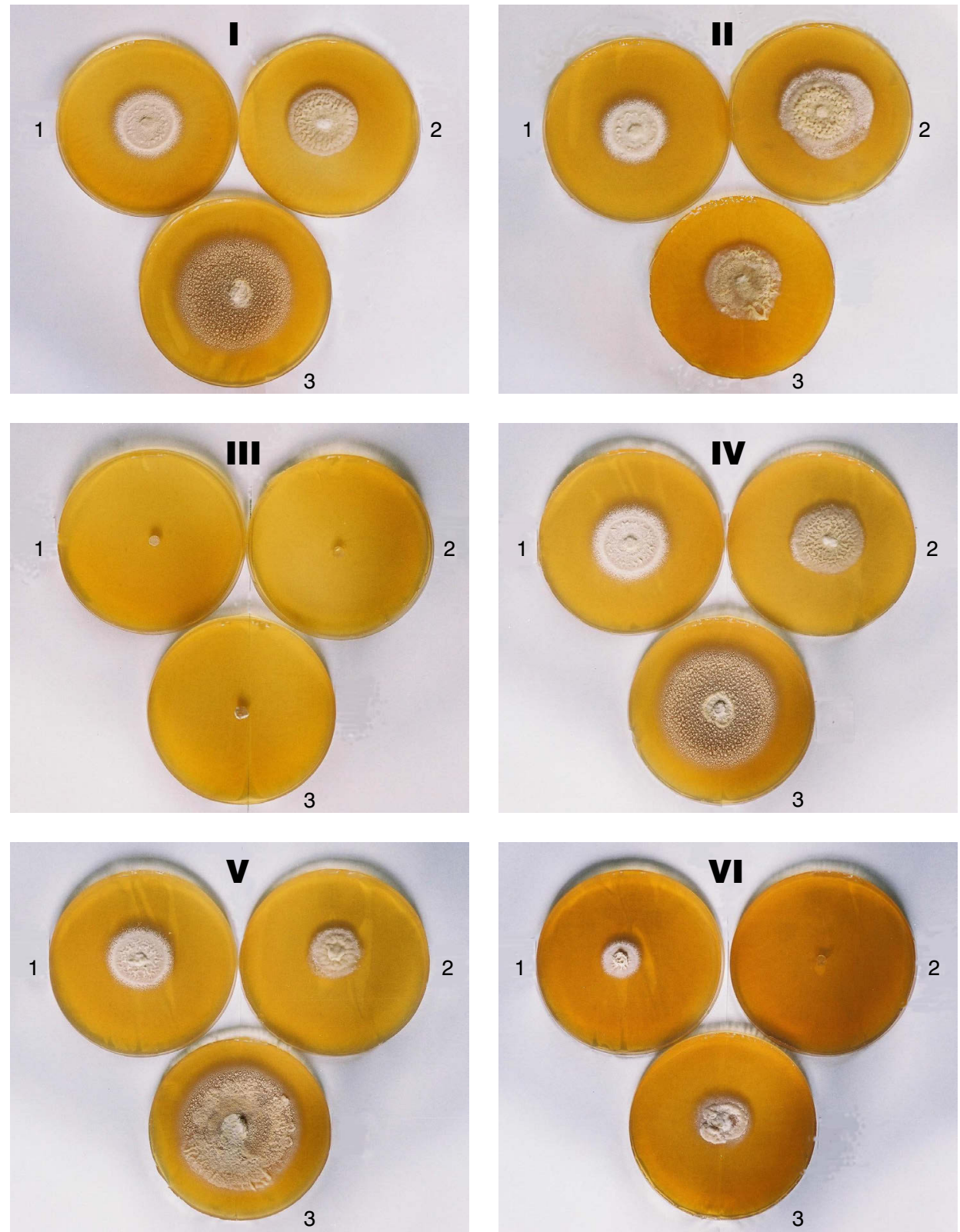

Fig. 2A. Morphology and size of the mycelia of Z. aphrophora, Z lanceolata and Z. psyllae on media with different concentrations of buffers and $\mathrm{NaCl}$. 

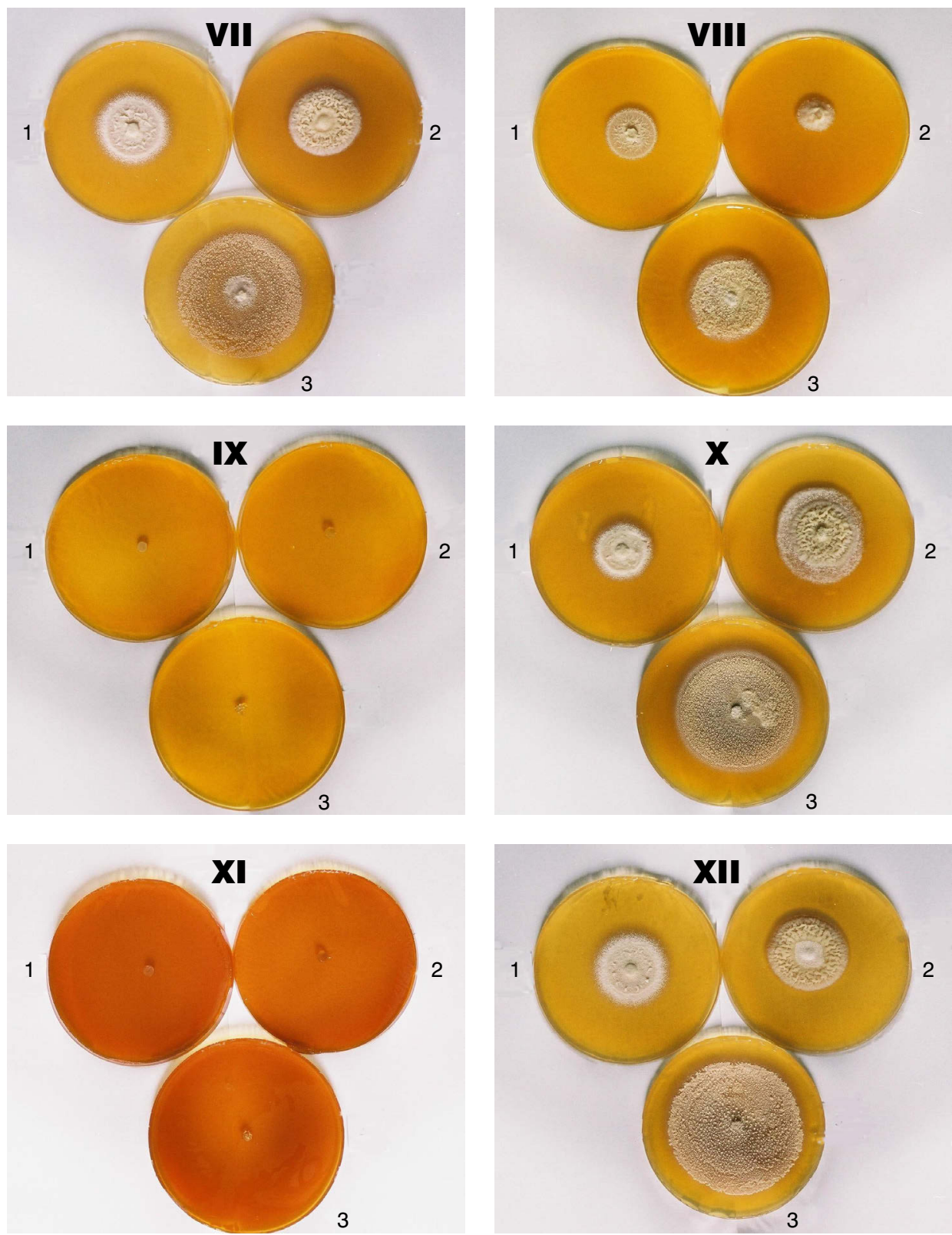

Fig. 2B. Morphology and size of the mycelia of Z. aphrophora, Z. lanceolata and Z. psyllae on media with different concentrations of buffers and $\mathrm{NaCl}$. 